\title{
Species richness and distribution patterns of echinoderms in the southwestern Atlantic Ocean (34-56 $\left.{ }^{\circ} \mathrm{S}\right)$
}

\author{
Valeria Souto ${ }^{1,2}$, Mariana Escolar ${ }^{2}$, Gabriel Genzano ${ }^{1}$, Claudia Bremec ${ }^{1,2}$ \\ ${ }^{1}$ Consejo Nacional de Investigaciones Científicas y Técnicas (CONICET), Rivadavia 1917, 1033AAj, Buenos Aires, \\ Argentina. Instituto de Investigaciones Marinas y Costeras (CONICET-UNMdP). \\ ${ }^{2}$ Instituto Nacional de Investigación y Desarrollo Pesquero (INIDEP), Paseo Victoria Ocampo 1, B7602HSA, \\ Mar del Plata, Argentina. E-mail: valeriasouto@inidep.edu.ar
}

\begin{abstract}
Summary: The aim of this study was to compile and analyse available historical information on echinoderms in the southwestern Atlantic Ocean in order to make a synthesis of present taxonomical knowledge, to identify patterns of geographical distribution of echinoderm assemblages and to test the validity of the current zoogeographic scheme for this group. This study was conducted on the Argentinean continental shelf, southwestern Atlantic Ocean (34-56 $\left.{ }^{\circ} \mathrm{S}\right)$. An intensive research on geo-referenced data was carried out to make a knowledge synthesis on echinoderm species and thus create a historical database. Multivariate analysis was used to analyse the faunal composition through latitudinal and bathymetric gradients as well as echinoderm associations. The results confirmed the existence of two faunal associations that correspond to the traditional zoogeographic scheme established for the Argentine Sea: the Argentinean and Magellan Provinces. The Argentinean Province had 46 widely distributed species. Of the 86 species recorded in the Magellan Province, a high percentage (25\%) were also found in Antarctic waters, suggesting a strong connection between the echinoderm fauna of this province and the Antarctic Region. The species richness between 34 and $56^{\circ} \mathrm{S}$ in the Atlantic Ocean showed a significant increase in reference to latitude, with the highest values being recorded between 46 and $56^{\circ} \mathrm{S}$. In view of the high percentage of shared species with Antarctica, considered a hot-spot region in terms of echinoderm diversity, the pattern of distribution of species richness observed in our study area could correspond to a dispersion of this species from Antarctic to sub-Antarctic regions.
\end{abstract}

Keywords: biodiversity, biogeography, distribution patterns, echinoderm, species richness, southwestern Atlantic.

Riqueza específica y patrones de distribución de equinodermos en el Atlántico Sudoccidental entre los 34 y $56^{\circ} \mathrm{S}$

Resumen: El objetivo de este estudio es recopilar y analizar la información histórica disponible sobre equinodermos en el Atlántico Sudoccidental, a fin de elaborar una síntesis del estado de conocimiento actual, identificar patrones de distribución geográfica de las comunidades de equinodermos y poner a prueba la validez del esquema zoogeográfico tradicionalmente establecido para el área de estudio. Este estudio se llevó a cabo en la Plataforma Continental Argentina entre los 34 y $56^{\circ} \mathrm{S}$. Se efectuó una intensiva búsqueda de datos geo-referenciados sobre las especies de equinodermos, a fin de crear una base de datos histórica. Se utilizaron análisis multivariados para analizar cambios en la composición específica a través de gradientes latitudinales y batimétricos, así como también para reconocer y diferenciar las asociaciones de equinodermos en el área de estudio. Los resultados confirmaron la existencia de dos asociaciones faunísticas que responden al esquema zoogeográfico tradicionalmente establecido para el área de estudio, distinguiendo dos Provincias Biogeográficas: Argentina y Magallánica. La Provincia Argentina presentó cuarenta y seis especies ampliamente distribuidas. Ochenta y seis especies fueron registradas en la Provincia Magallánica, un alto porcentaje de las mismas también se encontraron en aguas de la Antártida (25\%), lo que sugiere una fuerte conexión entre la fauna de equinodermos entre esta provincia y la Región Antártica. La riqueza de especies entre los 34 y $56^{\circ} \mathrm{S}$ en el Océano Atlántico mostró un aumento significativo en referencia a la latitud, los valores más altos se registraron entre los 46 y $56^{\circ} \mathrm{S}$. En vista del alto porcentaje de especies compartidas con la Antártida, considerada una región con una diversidad muy alta de equinodermos, el patrón de distribución de la riqueza de especies observado en el área de estudio podría responder a una dispersión de especies antárticas hacia aguas subantárticas.

Palabras clave: biodiversidad; biogeografía; patrones de distribución: equinodermos; riqueza específica; Atlántico Sudoccidental.

Citation/Como citar este artículo: Souto V., Escolar M., Genzano G., Bremec C. 2014. Species richness and distribution patterns of echinoderms in the southwestern Atlantic Ocean (34-56 ${ }^{\circ}$ S). Sci. Mar. 78(2): 269-280. doi: http://dx.doi. org/10.3989/scimar.03882.26B

Editor: W.E. Arntz.

Received: May 7, 2013. Accepted: January 27, 2014. Published: May 26, 2014.

Copyright: (C) 2014 CSIC. This is an open-access article distributed under the Creative Commons Attribution-Non Commercial Lisence (by-nc) Spain 3.0. 


\section{INTRODUCTION}

Echinoderms are benthic marine invertebrates widely distributed throughout the world ocean. In southern South America, this group was early studied by L. Feuillée at the beginning of 1770 (Larraín 1995); during the following centuries, most information from the Atlantic Ocean was produced on the basis of material collected by HMS Challenger (1873-1876) and RV Discovery (1925-1936) (Mortensen 1936, Fisher 1940). The early work on taxonomy and biology of echinoderms of the Argentine Sea are contributions about echinoids, asteroids and ophiuroids of southern South America (Bernasconi 1947, 1964a,b,c, Bernasconi and D'Agostino 1977). More recently, inventories have been developed in north Patagonian gulfs (Zaixso and Lizarralde 2000) and in the Straits of Magellan (Larraín et al. 1999, Mutschke and Ríos 2006), which provide lists of species of echinoderms collected in particular environments. Other contributions have shown the distribution patterns of the most conspicuous species in large Atlantic shelf areas, between 26 and $38^{\circ} \mathrm{S}$ (Tommasi et al. 1988a,b), and along the shelf break frontal area, between 36 and $43^{\circ} \mathrm{S}$ (Escolar 2010).

The assessment of biodiversity in terms of species richness in marine systems is important to understand the ecological patterns of species distribution as well as the functioning of ecosystems, and to manage the use of marine resources and the identification of priorities for conservation (Gray 2001). Anthropogenic impacts and the need for systematic conservation planning have prompted further analyses of the patterns of diversity (Worm et al. 2006).

The current zoogeographic scheme established for the southwestern Atlantic between 34 and $56^{\circ} \mathrm{S}$, with the Argentine and Magellan Provinces (Balech 1954), has been confirmed for various groups of invertebrates in recent work on amphipods (López Gappa et al. 2006), hydroids (Genzano et al. 2009) and polychaetes (Bremec et al. 2010a). In the case of echinoderms, a great biodiversity is found in the Argentine Sea. Most echinoderm species are distributed from southern Brazil and Uruguay to the Province of Buenos Aires in Argentina, or belong to the sub-Antarctic fauna that can reach southern Uruguay (Brogger et al. 2013). However, knowledge of the taxonomy, ecology and biogeography of echinoderms on the Argentinean continental shelf is still incomplete.

The aim of this study was to compile and analyse available historical information on echinoderms in the southwestern Atlantic, in order to make a synthesis of present taxonomical knowledge and to identify patterns of geographical distribution. A database with geo-referenced records of echinoderm species that covers the Argentinean and Uruguayan continental shelves was used for the first time to test the validity of the current zoogeographical scheme.

\section{MATERIALS AND METHODS}

\section{Study area}

This study was conducted on literature dealing with the area between 34 and $56^{\circ} \mathrm{S}$ and between the coast- line and $50^{\circ} \mathrm{W}$. The Argentinean continental shelf is characterized by the presence of two large water masses: a sub-Antarctic mass (the Malvinas Current) and a sub-tropical mass (the Brazil Current). The Malvinas current has a high primary productivity, and is a northward-running branch of the Subantarctic Cabo de Hornos Current, which has an influence on coastal and offshore areas. As it moves northward, the Malvinas Current is separate from the coast and affects only offshore waters. Mean temperature ranges yearly from 4 to $11^{\circ} \mathrm{C}$. Salinity ranges yearly from 33.8 to 34.4 . The Brazil Current is a branch of the South Equatorial Current; it moves from north to south along the Brazilian coast and reaches the coast of Buenos Aires. This water mass is less productive than the Malvinas Current; its mean temperature ranges yearly from 14 to $25^{\circ} \mathrm{C}$, and its salinity from 35 to 35.5. The Brazil and Malvinas Currents meet at the subtropical convergence approximately at $35^{\circ} \mathrm{S}$ (Boltovskoy 1981, Bastida et al. 1992).

The whole study area was divided into a $1^{\circ}$ square grid. The squares were numbered from west to east and from north to south, following a procedure applied for the study of other groups of benthic invertebrates (see López Gappa 2000, López Gappa and Landoni 2005, Montiel et al. 2005, López Gappa et al. 2006 and Genzano et al. 2009).

\section{Database}

An intensive search of geo-referenced data was carried out on the available literature to make a synthesis of taxonomic and distributional knowledge on echinoderms in order to create a historical database. Only data of presence and absence of species were used. We used taxonomic papers and other works published by specialists up to 2005. Valid species showing inaccurate locations, named in a single paper or found in a single location were excluded from the analyses.

\section{Data processing}

\section{Spatial distribution of species richness}

The study area was divided into degrees of latitude $\left(34-56^{\circ} \mathrm{S}\right)$ and species richness and the number of sampling stations/coastal localities were estimated for each latitude. A correlation (Spearman rank correlation coefficient) was made between the two variables (López Gappa et al. 2006). If this correlation was significant, the number of species per oceanographic station/coastal locality was calculated for each degree of latitude in the study area. Then, the Spearman rank correlation coefficient was calculated again between the new variable (number of species per oceanographic station/coastal locality) and latitude.

\section{Species composition through latitudinal and bathym- etric ranges}

The study area was divided into 12 areas (A-L) to evaluate the faunal composition of echinoderms through latitudinal and bathymetric gradients. The 


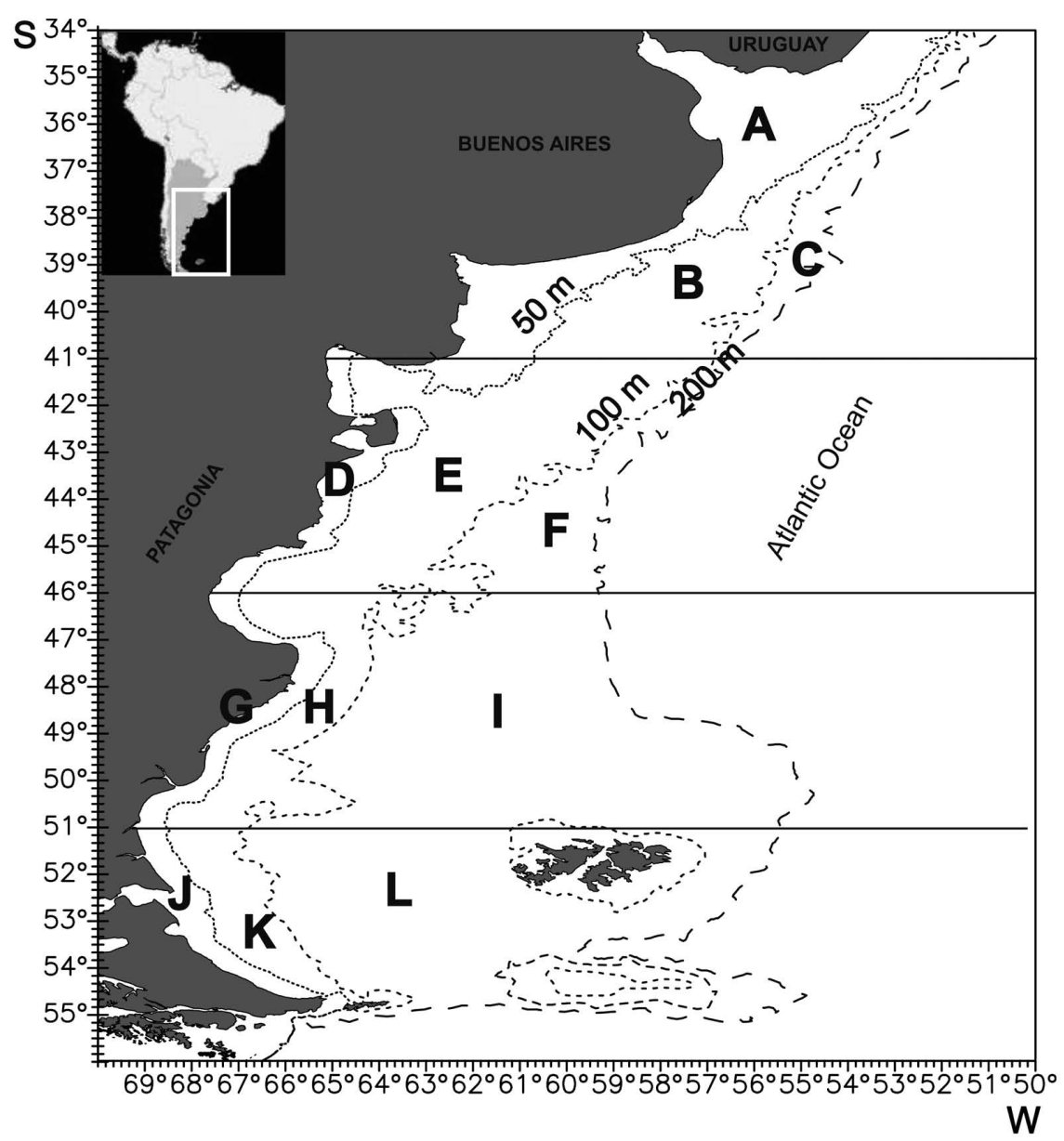

Fig. 1. - Study area showing the division into 12 zones used to analyse echinoderm species composition through latitudinal (34-56 $\mathrm{S})$ and bathymetric ranges $(0-3500 \mathrm{~m})$.

study area was also divided into four latitudinal bands according to different oceanographic and geophysical features:

1) Off Buenos Aires $\left(34-41^{\circ} \mathrm{S}\right)$. This region contains the subtropical/sub-Antarctic zone convergence, which is a product of the mixture of subtropical waters coming from the north, and sub-Antarctic waters. This convergence forms an area with specific oceanographic features, which is considered a transition area (Acha et al. 2004). This region also contains the Río de la Plata system, considered an important biogeographical barrier to many species.

2) Off Río Negro and Chubut (41-46 $\mathrm{S})$. The Valdes Peninsula tidal front develops in this sector.

3) Off Santa Cruz $\left(46-51^{\circ} \mathrm{S}\right)$. This area is characterized by low-salinity waters due to the discharge of continental waters and is also influenced by the contribution of Pacific waters through the Strait of Le Maire.

4) Off Tierra del Fuego and around the Malvinas Islands $\left(51-56^{\circ} \mathrm{S}\right)$. This area receives a major contribution of continental waters that form a salinity front, and is influenced by Antarctic waters due to the proximity to the Drake Passage, the northern boundary of the Antarctic Region.

Each of these latitudinal bands was divided into three sectors in accordance with bathymetry: $<50 \mathrm{~m}$, 50-100 m and >100 m. 12 areas were thus obtained
(Fig. 1). A matrix was made with the data of presence and absence of species contained in each of the 12 areas. An analysis of similarities (ANOSIM) was carried out (PRIMER 6.0, licensed software) to test the null hypothesis of no difference in species composition among the 12 areas (Clarke 1993, Clarke and Warwick 2001).

\section{Species assemblages}

In order to analyse the echinoderm associations in the study area, multivariate analyses (Clarke 1993, Clarke and Warwick 2001) (PRIMER 6.0, licensed software) were applied. We performed a cluster analysis among squares, using the Bray-Curtis similarity measures based on presence/absence data. A SIMPROF analysis was used to test whether the groups were significantly different. We applied the test of similarity percentage (SIMPER) to determine the contribution of each species to the similarity/dissimilarity within the group of squares. Finally, an ANOSIM among squares located in the Argentine Province (depths less than $60 \mathrm{~m}$, between 35 and $42^{\circ} \mathrm{S}$ ) and the Magellan Province (other squares) was performed to test the null hypothesis of no difference in species composition between the two biogeographic provinces traditionally established for the study area. 


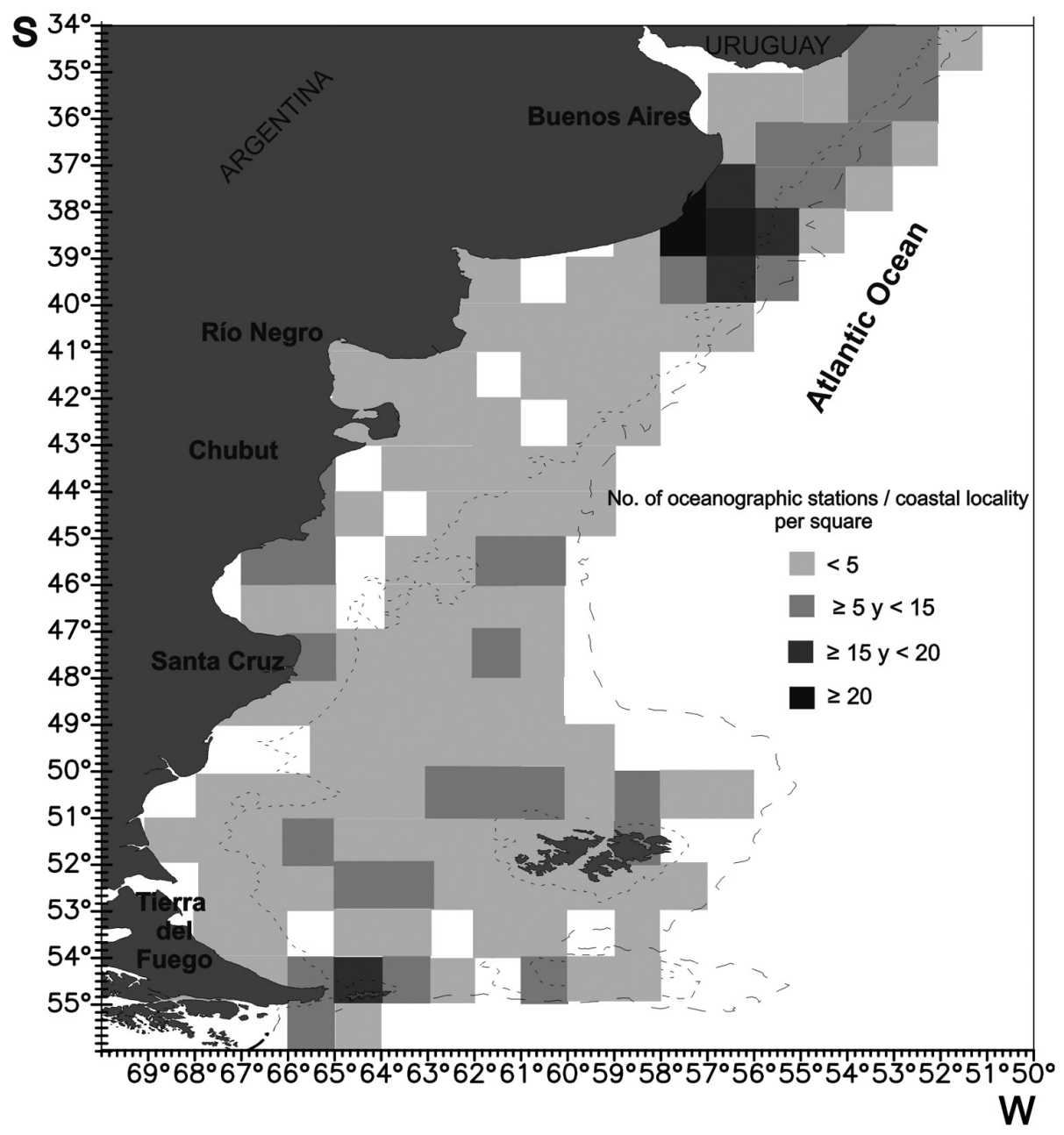

Fig 2. - Spatial distribution and coverage of sampling effort per square $\left(1 \times 1^{\circ}\right)$ in the study area, between 34 and $56^{\circ} \mathrm{S}$.

\section{RESULTS}

A total of 110 species of echinoderms distributed in 5 classes, 16 orders and 37 families were recorded in the study area (Appendix 1) according to the information available in 36 taxonomic and other published works up to 2005 (Appendix 2). Twenty species were not considered because of inaccurate locations, presence in only one location or only one report. Therefore, a matrix of 152 squares for 90 species was used in the analysis. The geographical coverage of sampling fully covers the study area, but there were areas with higher sampling intensity such as the coast of Uruguay, Buenos Aires, Chubut, Tierra del Fuego and the Malvinas Islands (Fig. 2).

The class Asteroidea presented the highest species richness (47 species) representing over $50 \%$ of the total; the species richness in Ophiuroidea, Echinoidea and Holothuroidea was 18, 11 and 14 species, respectively.

\section{Spatial distribution of species richness}

Given that species richness was biased by the sampling effort (Spearman rank correlation, $\mathrm{N}=22$, $\mathrm{R}=0.618, \mathrm{P}<0.01$ ) the variable "number of species per

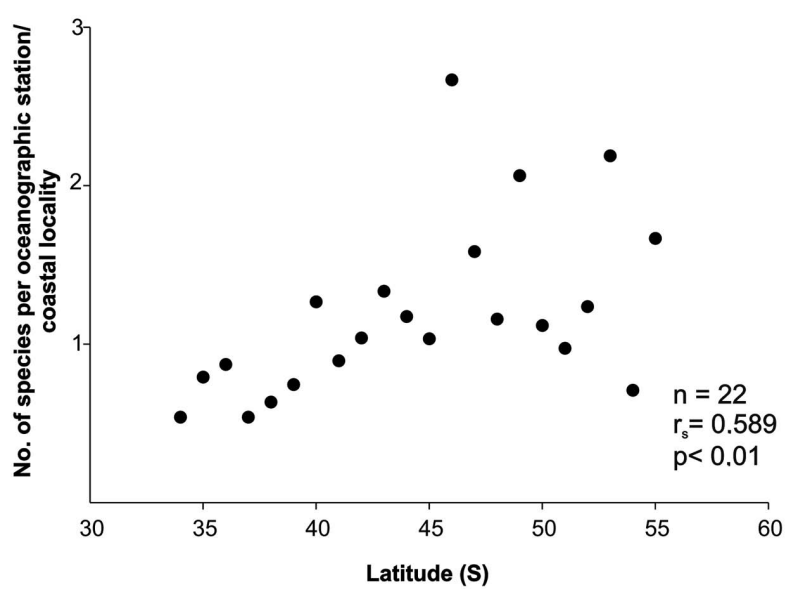

Fig. 3. - Relationship between latitude (S) and number of echinoderm species per oceanographic station/coastal locality in the study area.

oceanographic station/coastal locality" was used to analyse the relationship between richness and latitude. This correlation was positive (Spearman rank correlation, $\mathrm{N}=22, \mathrm{R}=0.589, \mathrm{P}<0.01$ ) and the highest values were recorded between 47 and $55^{\circ} \mathrm{S}$ (Fig. 3). 


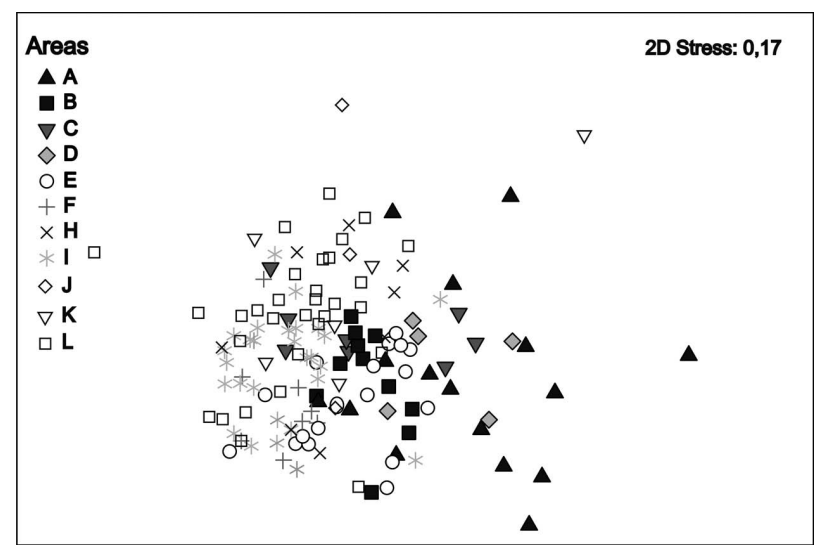

Fig. 4. - Multidimensional analysis (MDS) between 12 areas through latitudinal and bathymetric ranges based on presence and absence data of echinoderms.

\section{Species composition through latitudinal and bathymetric ranges}

The multidimensional scaling (MDS) showed a spatial separation between those areas further south and deeper than $100 \mathrm{~m}(\mathrm{C}, \mathrm{F}, \mathrm{I}, \mathrm{J}, \mathrm{K}$ and $\mathrm{L})$ and areas located between 34 and $51^{\circ} \mathrm{S}$ at depths less than 100 $\mathrm{m}$ (A, B, D and H) (Fig. 4). Moreover, the comparison in pairs was significantly different between Area A vs. I (ANOSIM, $\mathrm{R}=0.535, \mathrm{P}=0.01$ ), A vs. L (ANOSIM, $\mathrm{R}=0.422, \mathrm{P}=0.01$ ), $\mathrm{C}$ vs. $\mathrm{E}$ (ANOSIM, $\mathrm{R}=0.358$, $\mathrm{P}=0.01)$ and $\mathrm{D}$ vs. $\mathrm{F}$ (ANOSIM, $\mathrm{R}=0.629, \mathrm{P}=0.01$ ). Area $\mathrm{G}$ was not included in this analysis because it contained only a single square in which echinoderms were reported.

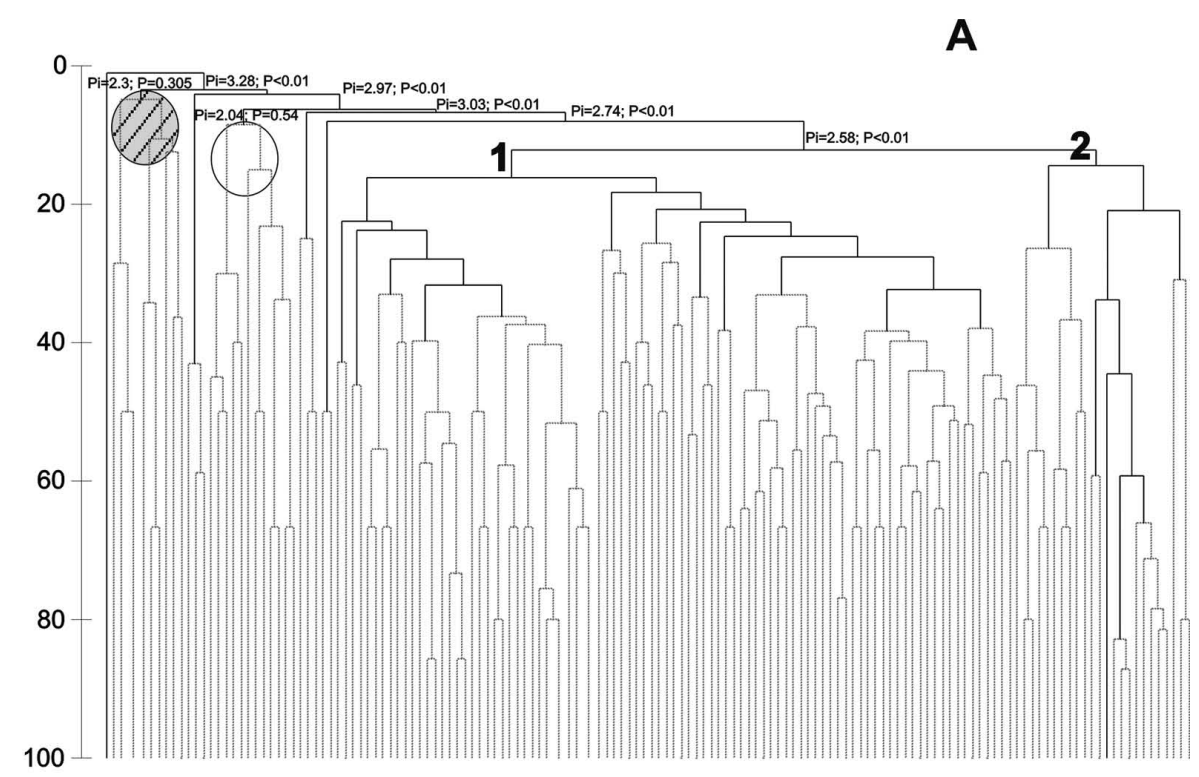

B

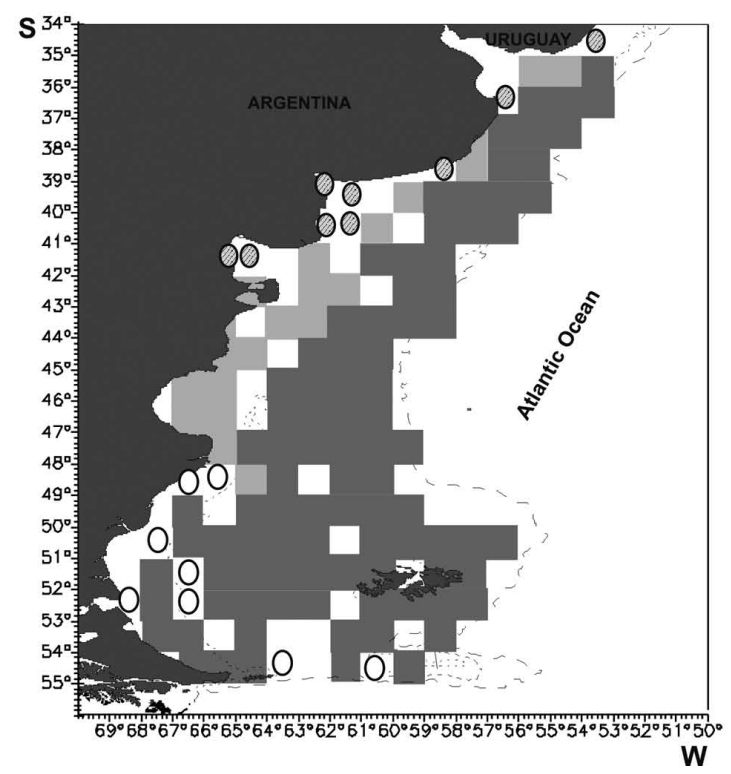

Fig. 5. - Echinoderm assemblages. A, SIMPROF analysis between squares. Values in the dendrogram show the significance in the formation of groups; and B, Geographic distribution in the study area. Group 1, dark grey squares; Group 2, light grey squares; coastal Buenos Aires and Uruguay, dashed circles; coastal Patagonia, white circles. 
Table 1. - SIMPER analysis results for the data of presence/absence of echinoderm species per square between groups 1 and 2 obtained with cluster analysis. Species are listed according to their contribution to the dissimilarity between groups. Av. Abund., average abundance; Av. Diss., average dissimilarity; Diss/SD, dissimilarity/standard deviation; Contrib.\%, percentage of contribution; Cum. \%, cumulative percentage.

\begin{tabular}{|c|c|c|c|c|c|c|}
\hline Species & Av. Abund. G1 & Av. Abund. G2 & Av. Diss. & Diss/SD & Contrib.\% & Cum. $\%$ \\
\hline Ctenodiscus australis & 0.71 & 0.14 & 5.48 & 0.87 & 6.24 & 6.24 \\
\hline Pseudechinus magellanicus & 0.25 & 0.73 & 4.87 & 0.82 & 5.54 & 11.78 \\
\hline Amphiura eugeniae & 0.11 & 0.64 & 3.86 & 0.85 & 4.4 & 16.18 \\
\hline Arbacia dufresni & 0.13 & 0.59 & 3.82 & 0.81 & 4.35 & 20.53 \\
\hline Cycethra verrucosa & 0.26 & 0.41 & 3.21 & 0.66 & 3.65 & 24.18 \\
\hline Ophiactis asperula & 0.43 & 0.45 & 3.1 & 0.82 & 3.53 & 27.71 \\
\hline Austrocidaris canaliculata & 0.34 & 0.36 & 2.69 & 0.75 & 3.07 & 30.78 \\
\hline Sterechinus agassizii & 0.29 & 0.23 & 2.54 & 0.64 & 2.9 & 33.68 \\
\hline Henricia obesa & 0.22 & 0.36 & 2.5 & 0.65 & 2.85 & 36.52 \\
\hline Hemioedema spectabilis & 0.05 & 0.45 & 2.42 & 0.76 & 2.75 & 39.27 \\
\hline Odontaster penicillatus & 0.33 & 0.14 & 2.36 & 0.63 & 2.69 & 41.96 \\
\hline Encope emarginata & 0.03 & 0.41 & 2.23 & 0.68 & 2.54 & 44.5 \\
\hline Tripylaster philippii & 0.22 & 0.18 & 2.02 & 0.53 & 2.31 & 46.81 \\
\hline Ophiocten amitinum & 0.3 & 0.05 & 1.99 & 0.57 & 2.27 & 49.08 \\
\hline Ophiomyxa vivipara & 0 & 0.41 & 1.86 & 0.76 & 2.12 & 51.2 \\
\hline Porianiopsis mira & 0.01 & 0.36 & 1.71 & 0.7 & 1.95 & 53.15 \\
\hline Astropecten $b$. brasiliensis & 0.02 & 0.18 & 1.62 & 0.39 & 1.85 & 54.99 \\
\hline Ophiacanta vivipara & 0.28 & 0.05 & 1.6 & 0.55 & 1.82 & 56.81 \\
\hline Diplopteraster verrucosus & 0.12 & 0.23 & 1.55 & 0.54 & 1.76 & 58.58 \\
\hline Diplasterias brandti & 0.23 & 0.14 & 1.53 & 0.58 & 1.74 & 60.32 \\
\hline Acodontaster e. granulíferus & 0.27 & 0 & 1.45 & 0.49 & 1.65 & 61.97 \\
\hline Cosmasterias lurida & 0.03 & 0.23 & 1.38 & 0.47 & 1.57 & 63.54 \\
\hline Cladodactyla crocea & 0.06 & 0.23 & 1.3 & 0.48 & 1.48 & 65.02 \\
\hline Labidiaster radiosus & 0.21 & 0 & 1.25 & 0.4 & 1.42 & 66.45 \\
\hline Chiridota pisanii & 0.03 & 0.27 & 1.22 & 0.59 & 1.39 & 67.84 \\
\hline Bathybiaster loripes & 0.07 & 0.09 & 1.13 & 0.36 & 1.28 & 69.12 \\
\hline Astrotoma agassizii & 0.19 & 0 & 1.11 & 0.41 & 1.26 & 70.38 \\
\hline Pseudocnus dubiosus leoninus & 0.09 & 0.18 & 1.07 & 0.5 & 1.22 & 71.6 \\
\hline Gorgonocephalus chilensis & 0.18 & 0.05 & 1.07 & 0.44 & 1.22 & 72.82 \\
\hline Ceramaster patagonicus & 0.14 & 0 & 0.98 & 0.34 & 1.12 & 73.94 \\
\hline Ganeria hahni & 0.04 & 0.18 & 0.95 & 0.41 & 1.08 & 75.02 \\
\hline Trachythyone parva & 0.15 & 0 & 0.89 & 0.37 & 1.02 & 76.04 \\
\hline Diplopteraster clarki & 0.09 & 0.05 & 0.87 & 0.31 & 0.99 & 77.02 \\
\hline Pteraster stellifer & 0.13 & 0 & 0.83 & 0.34 & 0.95 & 77.97 \\
\hline Abatus philippii & 0.09 & 0 & 0.81 & 0.27 & 0.92 & 78.89 \\
\hline Cycethra verrucosa verrucosa & 0.04 & 0.14 & 0.8 & 0.41 & 0.92 & 79.81 \\
\hline Ophiura lymani & 0.14 & 0 & 0.8 & 0.33 & 0.91 & 80.72 \\
\hline Ophioplocus januarii & 0 & 0.18 & 0.79 & 0.44 & 0.9 & 81.62 \\
\hline Ophioplinthus inornata & 0.11 & 0 & 0.75 & 0.26 & 0.86 & 82.48 \\
\hline Trachythyone peruana & 0.11 & 0 & 0.68 & 0.31 & 0.78 & 83.26 \\
\hline Luidia ludwigi scotti & 0.02 & 0.05 & 0.67 & 0.21 & 0.77 & 84.03 \\
\hline Pteraster affinis lebruni & 0.12 & 0 & 0.64 & 0.34 & 0.72 & 84.75 \\
\hline Anasterias antarctica & 0.07 & 0.05 & 0.59 & 0.31 & 0.67 & 85.42 \\
\hline Henricia studeri & 0.09 & 0 & 0.57 & 0.27 & 0.65 & 86.08 \\
\hline Anasterias pedicellaris & 0.08 & 0.05 & 0.57 & 0.32 & 0.64 & 86.72 \\
\hline Pentamera chiloensis & 0.01 & 0.14 & 0.56 & 0.4 & 0.64 & 87.36 \\
\hline Amphiodia planispina & 0.02 & 0.09 & 0.56 & 0.31 & 0.64 & 88 \\
\hline Pseudocnus perrieri & 0.11 & 0 & 0.56 & 0.32 & 0.64 & 88.64 \\
\hline Amphiura princeps & 0.01 & 0.14 & 0.55 & 0.4 & 0.62 & 89.27 \\
\hline Ophiochondrus stelliger & 0.08 & 0 & 0.55 & 0.27 & 0.62 & 89.89 \\
\hline Lophaster stellans & 0.08 & 0 & 0.5 & 0.27 & 0.57 & 90.46 \\
\hline Abatus cavernosus & 0.07 & 0.05 & 0.5 & 0.31 & 0.57 & 91.03 \\
\hline Porania (Porania) antarctica magellanica & 0.1 & 0 & 0.47 & 0.3 & 0.53 & 91.56 \\
\hline Asterina stellifera & 0 & 0.09 & 0.46 & 0.3 & 0.52 & 92.09 \\
\hline Amphiura magellanica & 0.05 & 0.05 & 0.46 & 0.27 & 0.52 & 92.61 \\
\hline Amphioplus albidus & 0.04 & 0.05 & 0.45 & 0.24 & 0.51 & 93.12 \\
\hline Ganeria falklandica & 0.01 & 0.09 & 0.42 & 0.32 & 0.48 & 93.6 \\
\hline Taeniogyrus contortus & 0.04 & 0.05 & 0.42 & 0.25 & 0.47 & 94.07 \\
\hline
\end{tabular}

\section{Species assemblages}

The cluster analysis indicated two main groups (group 1 and group 2) and two small groups of a few squares, mostly covering coastal waters between 34 and $42^{\circ} \mathrm{S}$ (Uruguay and Buenos Aires) and between 48 and $55^{\circ} \mathrm{S}$ (Patagonia) (Fig. 5A). There was an average dissimilarity equal to $88 \%$ between groups 1 and 2 ; the contribution of each of the species included in the study can be found in Table 1 (SIMPER test, presenceabsence data). Group 1 (21\% internal similarity) was composed of 90 squares occupying mainly shelf areas: between 34 and $48^{\circ} \mathrm{S}$ at depths greater than $50 \mathrm{~m}$ and between 48 and $55^{\circ} \mathrm{S}$ from shallow to deeper waters (Fig. 5B). In this sector, 86 species of echinoderms were registered, $48 \%$ exclusive. The species that most contributed to internal similarity of the group were Ctenodiscus australis, Ophiactis asperula, Odontaster penicillatus, Ophiocten amitinum, Austrocidaris canaliculata, Sterechinus agassizii, Ophiacantha vivipara, Tripylaster phillippi, Acodontaster e. granuliferus, Labidiaster radiosus, Astrotoma agassizii and Gorgonocephalus chilensis. Group 2 (27\% internal similarity) was composed of 21 squares encompassing coastal and 
relatively shallow shelf areas, between 34 and $48^{\circ} \mathrm{S}$ and in general at depths of less than $60 \mathrm{~m}$ (Fig. 5). In this sector, 48 species of echinoderms were recorded. The most frequent species of this assemblage were Pseudechinus magellanicus, Arbacia dufresnii, Amphiura eugeniae, Cycethra verrucosa, Hemioedema spectabilis, Encope emarginata, Porianopsis mira, Cosmasterias lurida, Astropecten b. brasiliensis, Cladodactyla crocea, Pentamera chiloensis and Chiridota pisanii (Table 1).

The results of the ANOSIM analysis between squares from the Argentinean and Magellan Provinces showed significant differences in the echinoderm species composition (global $\mathrm{R}=0.339, \mathrm{P}=0.01$ ), and lead to the rejection of our null hypothesis.

\section{DISCUSSION}

We analysed the presence and distribution of 110 species of echinoderms, distributed in 5 classes, 16 orders and 37 families in the southwestern Atlantic. However, our analyses were performed with the most frequent species $(\mathrm{N}=90)$, in agreement with Brogger et al. (2013) in a recent contribution. It is interesting to point out that Crinoidea Antedonidae were early reported by Mortensen $(1917,1920)$ and Bremec et al. (2010b) on the Argentinean slope, but excluded in this study due to their scarcity.

A biased distribution of the sampling effort occurred in the study area, a fact already reported for other groups of benthic invertebrates in the Argentine Sea (López Gappa 2000, López Gappa and Landoni 2005, López Gappa et al. 2006). Although geographic coverage of historical sampling is wide, certain coastal areas have been sampled more intensively than others; this was the case of coastal bottoms of Uruguay, Buenos Aires, Chubut, Tierra del Fuego and the Malvinas Islands, where the number of species found could be a good estimation of species richness.

The latitudinal gradient in species richness is largely documented in both terrestrial and marine environments (Brown and Lomolino 1998). The most clearly observed pattern occurs in the northern hemisphere, with the highest richness in the tropics and decreasing towards the polar regions (Roy et al. 1998, Crame 2000, Hillebrand 2004). In the southern hemisphere, there is no clear evidence of any increase in species richness from Antarctica towards the Equator (Crame 2000, Valdovinos et al. 2003, Barnes and Griffiths 2008). The results of this study indicated that species richness of echinoderms in the southwestern Atlantic increases significantly with latitude (between 34 and $56^{\circ} \mathrm{S}$ ); the highest species richness was observed between 46 and $56^{\circ} \mathrm{S}$ in the Argentine Sea. A similar pattern was observed for Bryozoa (López Gappa and Lichtschein 1988, López Gappa 2000), Porifera (López Gappa and Landoni 2005) and Amphipoda (López Gappa et al. 2006) in the southwestern Atlantic and for Mollusca (Valdovinos et al. 2003) and Polychaeta (Lancellotti and Vásquez 2000; Hernández et al. 2005) along the southeast Pacific coast. Some authors postulate that the main component that generates this asymmetry of spe- cies richness in the latitudinal pattern, in comparison with the northern hemisphere, is the high species richness in the Antarctic Region (Griffiths et al. 2009). In particular, echinoderms are well represented on both sides of the Drake Passage (Arntz et al. 2005). Antarctica is considered a "hot-spot" in terms of echinoderm diversity (O’Loughlin et al. 2011). In addition, the Antarctic Region is the centre of origin and radiation of various taxa; many species that originated in the region have been able to migrate to cold temperate waters surrounding the sub-Antarctic region (Briggs 2006).

Specific composition of echinoderms changed through the studied bathymetric gradient, the most noticeable change being registered at depths greater than $100 \mathrm{~m}$

The bathymetric distribution patterns of echinoderms have been explained by physical factors (pressure, temperature, dissolved oxygen and sediment quality) and biological factors (mode of larval dispersal, predation and intra-and inter-specific competition) (Sokolova 1972, Gage and Tyler 1982, Ventura and Fernandes 1995), which could be modified through the bathymetric gradient. According to Iken et al. (2010), the echinoderm associations could be structured by different variables; a complex framework is generated and no single variable could explain the observed patterns. In our study area, the bathymetric gradient coincides with a water temperature gradient: we found shallow and warm waters in coastal areas, which became deeper and colder as we moved forward to the shelf break. Water temperature is considered the main limiting factor in the distribution of marine species (Stuardo 1964, Vannucci 1964, Menni et al. 2010, Okolodkov 2010) and has been the basis of many discussions on the boundaries between biogeographic provinces in the southwestern Atlantic (Ekman 1953, Boltovskoy 1964). The subtropical/sub-Antarctic convergence develops into the Argentinean Province; this mass of water is the product of the mixture of subtropical waters coming from the north transported by the Brazil Current and the sub-Antarctic waters arriving from the south carried by the Malvinas Current (Boltovskoy 1981, Acha et al. 2004).

Changes in the benthic faunal composition at depths greater than $100 \mathrm{~m}$ on the Argentinean Continental Shelf have been reported by other authors (Bastida et al. 1992, Escolar et al. 2013). These changes were explained in terms of the high productivity of the shelf break frontal system in the area, which is produced by the meeting of the sub-Antartic shelf waters and the cooler and more productive waters of the Malvinas Current (Acha et al. 2004).

The inventory and analysis of historical information about echinoderms conducted in this paper constitutes the first attempt to validate the preliminary biogeographical observations (see Bernasconi 1964c) and confirms the two main zoogeographic divisions of the study area, the Argentinean and Magellan Provinces (Balech 1954). The results of this study showed that the association of squares that represented the Argentinean Province was characterized by widely distributed species: there are subtropical (Asterina stel- 
lifera, Encope emarginata, Astropecten b. brasiliensis) (Tommasi 1970, Tommasi et al. 1988a,b, Martínez 2008) and sub-Antarctic species (Pseudechinus magellanicus, Arbacia dufresnii, Cycethra verrucosa, Porianopsis mira, Cosmasterias lurida) (Bernasconi 1947, 1964c, Tommasi 1965, Escolar 2010). These results show that the Argentinean Province is characterized by low endemism and has high heterogeneity (Balech and Ehrlich 2008) owing to its particular hydrography, as explained above.

Our results confirm the extension of the Magellan Province towards lower latitudes. We found that typically Magellanic species such as Ctenodiscus australis, Acodontaster e. granuliferus, Austrocidaris canaliculata, Sterechinus agassizii and Tripylaster phillippi (Bernasconi 1964c) extend northwards along the Malvinas current up to $36^{\circ}-37^{\circ} \mathrm{S}$, but always at depths greater than $100 \mathrm{~m}$. Von Ihering (1927) was the first to mention the arrival of Magellanic fauna to Cabo Frio (Brazil) and several authors remark that this locality is the boundary between the Magellan and South Brazilian Provinces (Briggs 1974, Boschi 1976). Similar results were obtained with benthic amphipods (López Gappa et al. 2006).

Almost half of the 86 species recorded in the Magellan Province and also half of the 46 species recorded in the Argentinean Province were also recorded by Lancellotti and Vásquez (2000) in Chilean waters. Pérez-Ruzafa et al. (2013) found that echinoderm fauna from Chile is more closely related to Argentina than to Peru. In fact, they established two biogeographical provinces, the Peru-Chilean and the South American or Magellan Provinces. This continuum in the distribution of species between the Pacific and Atlantic Oceans has been found in various groups of marine organisms, and is the main reason for asserting that the Magellan Province extends south from $40^{\circ}-41^{\circ} \mathrm{S}$ in the Pacific Ocean to approximately $30^{\circ}-31^{\circ} \mathrm{S}$ in the Atlantic Ocean (Balech 1954, Briggs 1974). Several authors postulate that the opening of the Strait of Magellan 7000 years ago played an important role in the distribution and dispersal of species to create a corridor for the exchange of faunal elements between the two oceans (McCulloch and Davies 2001, Montiel et al. 2005). In contrast, a low similarity (only 7\%) was found between the echinoderm fauna from southern Brazil and the Magellan Province; Barboza et al. (2011) postulated that this result suggests a clear turnover of species from the subtropical Brazil towards temperate areas, mainly at Uruguayan latitudes.

The $25 \%$ of the echinoderm species recorded in the Magellan Province in this study were registered in Antarctic waters by Bernasconi 1959, 1964c, 1979, Bernasconi and D'Agostino 1978, Dahm 1999, ManjónCabeza and Ramos 2003, Chiantore et al. 2006, De Domenico et al. 2006, O'Loughlin et al. 2011. These results confirm that there is a high degree of affinity between Antarctic and sub-Antartic echinoderm fauna previously mentioned by Barboza et al. (2011). The faunal connection between the sub-Antarctic Region of the Magellan Province and the Antarctic Region has also been reported for various groups of benthic invertebrates (Barnes and De Grave 2000, Montiel et al. 2005, Rodríguez et al. 2007). The presence of species on both sides of the Drake Passage provides strong evidence to confirm the faunal exchange between the Magellan Province and the Antarctic Region; therefore, it was inferred that the Polar Front is not a strict barrier to dispersion of many species of benthic invertebrates (Arntz and Brey 2003, Montiel et al. 2005).

It has been stated that echinoderm species could migrate from the Magellan Province through the Malvinas Plateau and shallow seas, following the arc of southern islands (the Scotia Arc) to reach the Antarctic: examples are Cycethra verrucosa, Anasterias antarctica, Arbacia dufresnii, Pseudechinus magellanicus (Bernasconi 1964c). The same pattern but in the opposite direction was reported by Hedgpeth (1969) for several species of Antarctic ophiuroids, such as Astrotoma agassizii, species with circumpolar Antarctic and sub-Antarctic distribution and with a wide dispersion northwards. Bernasconi and D'Agostino (1974) found this species at the northern end of the Antarctic Peninsula, South Georgia, Burdwood Bank and the Malvinas Islands, reaching $42^{\circ} \mathrm{S}$ in the Pacific Ocean and $39^{\circ} \mathrm{S}$ in the Atlantic Ocean). Hedgpeth (1969) also mention that the range of distribution of ophiuroids is controlled by depth, so the routes through shallow waters (Scotia Arc) have been of great importance in the spread of this and other classes of echinoderms.

Our results are in agreement with theories that attempt to explain the observed faunal affinities between Antarctica and South America, giving importance to the connection through the Scotia Arc (Arntz et al. 2005, Moyano 2005) and to the Antarctic Circumpolar Current and Antarctic Coastal Current in the case of echinoderms (Pawson 1969, Díaz et al. 2006).

\section{ACKNOWLEDGEMENTS}

We are grateful to Dr. Ana Roux for providing data collected during the cruises of FV Shinkai Maru (19781979). This is INIDEP Contribution $\mathrm{N}^{\circ} 1862$. Financial support was received from PICT 2007-02200 and EXA-UNMdP 546. V.S. is supported by a CONICET Doctoral Fellowship.

\section{REFERENCES}

Acha E.M., Mianzan H.W., Guerrero R.A. et al. 2004. Marine fronts at the continental shelves of austral South America. Physical and Ecological processes. J. Mar. Syst. 44: 83-105. http://dx.doi.org/10.1016/j.jmarsys.2003.09.005

Arntz W., Brey T. 2003. The expedition ANTARKTIS XIX/5 (LAMPOS) of RV Polarforsch. 462: 1-120.

Arntz W., Thatje S., Gerdes D. et al. 2005. The Antarctic-Magellan connection: macrobenthos ecology on the shelf and upper slope, a progress report. Sci. Mar. 69(Suppl. 2): 237-269.

Balech E. 1954. División zoogeográfica del litoral sudamericano. Rev. Biol. Mar. 4: 184-195.

Balech E., Ehrlich M.D. 2008. Esquema biogeográfico del Mar Argentino. Rev. Invest. Desarr. Pesq. 19: 45-75.

Barboza C., Bendayan de Moura R., Monnerat Lana A. et al. 2011. Echinoderms as clues to Antarctic - South American connectivity. Oecologia Australis 15: 86-110. http://dx.doi.org/10.4257/oeco.2011.1501.08

Barnes D.K., De Grave S. 2000. Biogeography of Southern Ocean bryozoans. Vie Milieu. 50: 261-273. 
Barnes D.K.A., Griffiths H.J. 2008. Biodiversity and biogeography of southern temperate and polar bryozoans. Glob. Ecol. Biogeogr. 17: 84-99.

Bastida R., Roux A., Martínez D. 1992. Benthic communities of the Argentine continental shelf. Oceanol. Acta 15: 687-698.

Bernasconi I. 1947. Distribución geográfica de los Equinoideos argentinos. An. Soc. Argent. Est. Geog. 8: 97-114.

Bernasconi I. 1959. Algunos asteroideos de Antártida. Contrib. Cient. Inst. Antart. Argent. 1: 2-22.

Bernasconi I. 1964a. Asteroideos argentinos. Claves para los órdenes, familias, subfamilias y géneros. Physis 24: 241-277.

Bernasconi I. 1964b. Asteroideos argentinos V. Familia Ganeriidae. Rev. Mus. Argent. Cienc. Nat. Bernardino Rivadavia Inst. Nac. Invest. Cienc. Nat. (Argent) Zo. 9: 59-89

Bernasconi I. 1964c. Distribución geográfica de los Equinoideos y Asteroideos de la extremidad austral de Sudamérica. Bol. Inst. Biol. Mar. 7: 43-50.

Bernasconi I. 1979. Asteriidae, Cosconasteriinae de la Argentina y Antártida. Rev. Mus. Argent. Cienc. Nat. Bernardino Rivadavia Inst. Nac. Invest. Cienc. Nat. (Argent) Hid. 5: 241-249.

Bernasconi I., D’Agostino M. 1974. Ampliación de la Zona de distribución de Amphiura crassipes Ljungman, 1867 (Ophiuroidea, Amphiuridae). Physis 33: 135-138.

Bernasconi I., D’Agostino M. 1977. Ofiuroideos del mar epicontinental argentino. Rev. Mus. Argent. Cienc. Nat. Bernardino Rivadavia Inst. Nac. Invest. Cienc. Nat. (Argent) Hid. 5: 65-123.

Bernasconi I., D’ Agostino M. 1978. Equinodermos Antárcticos III. Ofiuroideos de Sandwich del Sur y Georgias del Sur. Rev. Mus. Argent. Cienc. Nat. Bernardino Rivadavia Inst. Nac. Invest. Cienc. Nat. (Argent) Hid. 5: 203-222.

Boltovskoy E. 1964. Provincias zoogeográficas de América del Sur y su sector Antárctico según los foraminíferos bentónicos. Bol. Inst. Biol. Mar. 7: 93-99.

Boltovskoy E. 1981. Masas de agua en el Atlántico Sudoccidental. Atlas del Atlántico Sudoccidental y métodos de trabajo con el zooplancton marino. Publ. Espec. INIDEP, Mar del Plata, 10 pp.

Boschi E. 1976. Nuevos aportes al conocimiento de la distribución geográfica de los crustáceos decápodos del Mar Argentino. Physis 35: 59-68.

Bremec C., Souto V., Genzano G. 2010a. Polychaete assemblages in SW Atlantic: Results of "Shinkai Maru" IV, V, X and XI (1978-1979) cruises in Patagonia and Buenos Aires. An. Inst. Patagon. (Chile) 38: 47-57. http://dx.doi.org/10.4067/S0718-686X2010000200005

Bremec C., Marecos A., Escolar M. et al. 2010b. Riqueza específica en los bancos comerciales de vieira patagónica (Zygochlamys patagonica) a lo largo del frente de talud. Período 2009. Inf. Invest. INIDEP, 22, $18 \mathrm{pp}$.

Briggs J.C. 1974. Marine Zoogeography. McGraw-Hill Co., New York, $475 \mathrm{pp}$.

Briggs J.C. 2006. Proximate sources of marine biodiversity. J. Biogeogr. 33: 1-10. http://dx.doi.org/10.1111/j.1365-2699.2005.01374.x

Brogger M., Gil D., Rubilar T. et al. 2013. Echinoderms from Argentina: Biodiversity, distribution and current state of knowledge. In Alvarado J., Solís-Marín F.A. (eds), Echinoderm Research and Diversity in Latin America. Springer-Verlag, Berlin Heidelberg, pp. 359-402. http://dx.doi.org/10.1007/978-3-642-20051-9_11

Brown J.H., Lomolino M.V. 1998. Biogeography, 2nd edn. Sinauer, Sunderland.

Chiantore M., Guidetti M., Cavallero M. et al. 2006. Sea urchins, sea stars and brittle stars from Terra Nova bay (Ross Sea, Antarctica). Polar Biol. 29: 467-475. http://dx.doi.org/10.1007/s00300-005-0077-2

Clarke K.R. 1993. Non-parametric multivariate analyses of changes in community structure. Aust. J. Ecol. 18: 117-143. http://dx.doi.org/10.1111/j.1442-9993.1993.tb00438.x

Clarke K.R., Warwick R.M. 2001. Change in Marine Communities: An approach to Statistical Analysis and Interpretation. PRIMER-E, Plymouth, $177 \mathrm{pp}$

Crame J.A. 2000. Evolution of taxonomic Diversity gradients in the marine realm: evidence from the composition of recent bivalve faunas. Paleobiology 26: 188-214. http://dx.doi.org/10.1666/0094-8373(2000)026<0188:EOTDG $\mathrm{I}>2.0 . \mathrm{CO} ; 2$

Dahm C. 1999. Ophiuroids (Echinodermata) of southern Chile and the Antarctic: Taxonomy, biomass, diet and growth of dominant species. Sci. Mar. 63: 427-432.

De Domenico F., Chiantore M., Buongiovanni, S. et al. 2006. Lati- tude versus local effects on echinoderm assemblages along the Victoria Land Coast, Ross Sea, Antarctica. Antarc. Sci. 18. 655-662.

http://dx.doi.org/10.1017/S095410200600068X

Díaz A., Palma A., Feral J. et al. 2006. Phylogeography of Sterechinus sea urchins in the Southern Ocean: a Antarctic and Subantarctic two-ring model. II Simposio Latinoamericano sobre Investigaciones Antárticas, 16-18 Agosto 2006, Concepción, Chile.

Ekman S. 1953. Zoogeography of the Sea. London, Sidwick \& Jackson, $417 \mathrm{pp}$.

Escolar M. 2010. Variaciones espacio-temporales en la comunidad de invertebrados bentónicos asociada al frente de talud. Equinodermos como caso de estudio. PhD Thesis. Univ. Buenos Aires, Argentina, 189 pp.

Escolar M., Hernández D.R., Bremec C. 2013. Latitudinal and bathymetric distribution patterns of ophiuroids (Echinodermata: Ophiuroidea) on scallop fishing grounds at the shelf-break frontal system, South-Western Atlantic. Mar. Biodiver. Rec. 6: 1-8.

Fisher W.K. 1940. Asteroidea. Discovery Reports XX: 69-306.

Gage J., Tyler P.A. 1982. Depth-related gradients in size structure and the bathymetric zonation of deep-sea brittle stars. Mar. Biol. 71: 299-308 http://dx.doi.org/10.1007/BF00397046

Genzano G.N., Giberto D., Schejter L. et al. 2009. Hydroid assemblages from the South-western Atlantic Ocean (34-42 $\left.{ }^{\circ} \mathrm{S}\right)$. Mar. Ecol. 30: 33-46. http://dx.doi.org/10.1111/j.1439-0485.2008.00247.x

Griffiths H., Barnes D., Linse K. 2009. Towards a generalized biogeography of the Southern Ocean benthos. J. Biogeogr. 36: $162-177$ http://dx.doi.org/10.1111/j.1365-2699.2008.01979.x

Gray J. 2001. Antarctic marine benthic biodiversity in a world-wide latitudinal context. Polar Biol. 24: 633-641. http://dx.doi.org/10.1007/s003000100244

Hedgpeth J.W. 1969. Introduction to Antarctic zoogeography: Distribution of selected groups of marine invertebrates in waters south of $35^{\circ} \mathrm{S}$ latitude. In: Bushnell V.C., Hedgpeth J.W. (eds), Antarctic Map Folio Series, American Geographical Society, New York, pp. 11: 1-9.

Hernández C.E., Moreno R.A., Rozbaczylo N. 2005. Biogeographical patterns and Rapoport's rule in southeastern Pacific benthic polychaetes of the Chilean coast. Ecography 28: 363-373. http://dx.doi.org/10.1111/j.0906-7590.2005.04013.x

Hillebrand H. 2004. On the Generality of the Latitudinal Diversity Gradient. Am. Nat. 163: 192-211. http://dx.doi.org/10.1086/381004

Iken K., Konar B., Benedetti-Cecchi L. et al. 2010. Large-Scale spatial distribution patterns of echinoderms in nearshore rocky habitats. PLoS One 5: e13845. http://dx.doi.org/10.1371/journal.pone.0013845

Lancellotti D., Vásquez J. 2000. Zoogeografía de macroinvertebrados bentónicos de la costa de Chile: Contribución para la conservación marina. Rev. Chil. Hist. Nat. 73: 99-129. http://dx.doi.org/10.4067/S0716-078X2000000100011

Larraín A. 1995. Biodiversidad de equinodermos chilenos: Estado actual del conocimiento y sinopsis biosistemática. Gayana Zool. 59: 73-96.

Larraín A., Mutschke E., Riveros A. et al. 1999. Preliminary report on Echinoidea and Asteroidea (Echinodermata) of the Joint Chilean-German-Italian Magellan "Victor Hensen” Campaign, 17 October - 25 November 1994. Sci. Mar. 63: 433-438. http://dx doi.org/10.3989/scimar.1999.63s1433

López Gappa J. 2000. Species richness of marine Bryozoa in the continental shelf and slope off Argentina (South-West Atlantic). Diversity Distrib. 6: 15-27 http://dx.doi.org/10.1046/j.1472-4642.2000.00067.x

López Gappa J., Lichtschein V. 1988. Geographic distribution of bryozoans in the Argentine Sea (South-Western Atlantic). Oceanol. Acta 11: 89-99.

López Gappa J., Landoni N. 2005. Biodiversity of Porifera in the Southwest Atlantic between $35^{\circ}$ and $56^{\circ} \mathrm{S}$. Rev. Mus. Argent. Cient. Nat. 7: 191-219.

López Gappa J., Alonso G.M., Landoni N. 2006. Biodiversity of benthic Amphipoda (Crutacea: Peracarida) in the Southwest Atlantic between $35^{\circ}$ and $56^{\circ} \mathrm{S}$. Zootaxa 1342: 1-66.

Manjón-Cabeza M., Ramos A. 2003. Ophiuroid community structure of the South Shetland Islands and Antarctic Peninsula Region. Polar Biol. 26: 691-699. http://dx.doi.org/10.1007/s00300-003-0539-3 
Martínez S. 2008. Shallow water Asteroidea and Ophiuroidea of Uruguay: composition and biogeography. Rev. Biol. Trop. 56: 205-214.

McCulloch R., Davies S. 2001. Late-glacial and holocene palaeoenvironmental change in the central Strait of Magellan, southern Patagonia. Palaeogeogr. Palaeoclimatol. Palaeoecol. 173: 143-173. http://dx.doi.org/10.1016/S0031-0182(01)00316-9

Menni R., Jaureguizar A., Stehmann M. et al. 2010. Marine biodiversity at the community level: zoogeography of sharks, skates, rays and chimaeras in the southwestern Atlantic. Biodiversity Conserv.19: 775-796. http://dx.doi.org/10.1007/s10531-009-9734-z

Mortensen T. 1917. The Crinoidea of the Swedish Antarctic Expedition. Wiss Ergebn. Schwed. Südpolar Exp. 8: 10-15.

Mortensen T. 1920. The Crinoidea. Wiss Ergebn Schwed Südpolar Exp 6: 1-24

Mortensen T. 1936. Echinoidea and Ophiuroidea. Discovery Reports XII: $109-348$.

Montiel A., Gerdes D., Arntz W.E. 2005. Distributional patterns of shallow-waters polychaetes in the Magellan Region: a zoogeographical and ecological synopsis. Sci. Mar. 69: 123-133.

Moyano H. 2005. Scotia Arc bryozoans from the LAMPOS expedition: a narrow bridge between two different faunas. Sci. Mar. 69: 103-112.

Mutschke E., Ríos C. 2006. Distribución espacial y abundancia relativa de los equinodermos en el Estrecho de Magallanes, Chile. Cienc. Tecnol. Mar. (Valpso) 29: 91-102.

Okolodkov Y. 2010. Biogeografía Marina. Universidad Autónoma de Campeche. 217 p.

O'Loughlin P., Paulay G., Davey N. et al. 2011. The Antarctic Region as marine biodiversity hot spot for echinoderms: Diversity and diversification of sea cucumbers. Deep Sea Res. Part II, 58: 254-275.

Pawson D. 1969. Holothuroidea fron Chile. Rep No 46 Lund Univ. Chile Exped. 1948-1949. Sarsia 38: 121-145.

Pérez-Ruzafa A., Alvarado J.J., Solís-Marín F.A. et al. 2013. Latin America Echinoderm Biodiversity and Biogeography: Patterns and Affinities. In Alvarado J., Solís-Marín F.A. (eds), Echinoderm Research and Diversity in Latin America. SpringerVerlag, Berlin Heidelberg, pp. 511-542. http://dx.doi.org/10.1007/978-3-642-20051-9 16

Rodríguez E., López-González P., Gili J. 2007. Biogeography of Antarctic sea anemones (Anthozoa, Actiniaria): What do they tell us about the origin of the Antarctic benthic fauna? Deep-Sea
Res. Part II. 54: 1876-1904. http://dx.doi.org/10.1016/j.dsr2.2007.07.013

Roy K., Jablonski D., Valentine J. et al. 1998. Marine latitudinal diversity gradients: tests of causal hypotheses. PNAS. 95: 3699-3702.

http://dx.doi.org/10.1073/pnas.95.7.3699

Sokolova M.N. 1972. Trophic structure of deep-sea macrobenthos. Mar. Biol. 16: 1-12. http://dx.doi.org/10.1007/BF00347841

Stuardo B. 1964. Distribución de los moluscos marinos litorales en Latinoamérica. Bol. Inst. Biol. Mar. 7: 79-91.

Tommasi L. 1965. Faunistic provinces of the western South Atlantic littoral Region (summary). Anais Acad. Bras. Cienc. 37: 261-262.

Tommasi L. 1970. Lista dos asteroides recentes N/Oc. "Almirante Saldanha” do Brasil. Contr. Avulsas Inst. Oceanogr. Univ. São Paulo Ser. Oceanogr. Biol. 18: 1-61. http://dx.doi.org/10.1590/S0373-55241969000100001

Tommasi L.R., de Castro S.M., de Sousa E. 1988a. Echinodermata coletados durante as campanhas oceanograficas do N/ Oc. "Almirante Saldanha" no Atlantico sul occidental. Relat. Interno Inst. Oceanogr. Univ. Sao Paulo 21, 11 pp.

Tommasi L.R., Cernea M., Condeixa M. 1988b. Equinodermes coletados pelo N/Oc. "Almirante Saldanha”, entre $26^{\circ} 59^{\prime} \mathrm{S}$ e $38^{\circ}$ 39'S. Relat. Interno Inst. Oceanogr. Univ. Sao Paulo 22, 11 pp.

Valdovinos C., Navarrete S., Marquet P. 2003. Mollusk species diversity in the Southeastern Pacific: why are there more species towards the pole? Ecography 26: 139-144. http://dx.doi.org/10.1034/j.1600-0587.2003.03349.x

Vannucci M. 1964. Zoogeografia marinha do Brasil. Bol. Inst. Biol. Mar. 7: 113-121.

Ventura C., Fernandes F. 1995. Bathymetric distribution and population size structure of paxillosid seastars (Echinodermata) in the Cabo Frío upwelling ecosystem of Brazil. Bull. Mar. Sci. 56: $268-282$.

Von Ihering H. 1927. Die geschichte des Atlantischen oceans. Gustav Fisher, Jena, 237 pp.

Worm B., Barbier E., Beaumont N. et al. 2006. Impacts of Biodiversity Loss on Ocean Ecosystem Services. Science 314: 787-790. http://dx.doi.org/10.1126/science.1132294

Zaixso H.E., Lizarralde Z. 2000. Distribución de equinodermos en el golfo San José y sur del golfo San Matías (Chubut, Argentina). Rev. Biol. Mar. Oceanogr. 35: 127-145. http://dx.doi.org/10.4067/S0718-19572000000100002

Appendix 1. - List of the species of Echinodermata recorded for the southwest Atlantic between 34 and $56^{\circ} \mathrm{S}$ and between $50^{\circ} \mathrm{W}$ and the coast of Argentina. Species with an asterisk $(*)$ were not included in subsequent analyses.

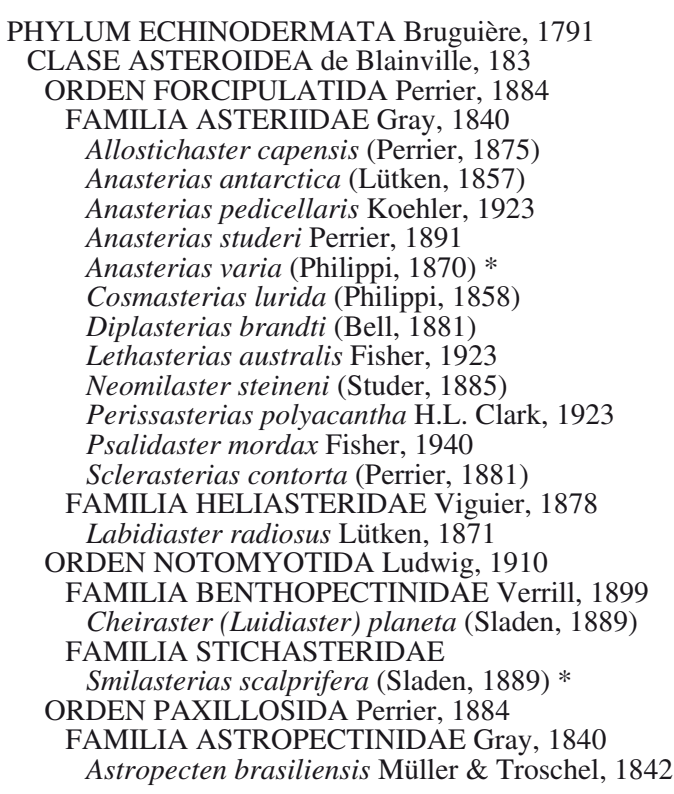

Astropecten b. brasiliensis Müller \& Troschel, 1842

Astropecten cingulatus Sladen, 1833

Bathydiaster loripes Sladen, 1889

Psilaster herwigi (Bernasconi, 1972)

Psilaster charcoti (Koehler, 1906)*

FAMILIA CTENODISCIDAE Sladen, 1889

Ctenodicus australis Lütken, 1871

FAMILIA LUIDIIDAE Sladen, 1889

Luidia alternata alternata (Say, 1825)

Luidia ludwigi scotti Bell, 1917

FAMILIA PSEUDARCHASTERIDAE

Pseudarchaster discus Sladen, 1889 *

ORDEN SPINULOSIDA Perrier, 1884

FAMILIA ECHINASTERIDAE Verrill, 1870

Henricia obesa (Sladen, 1889)

Henricia studeri Perrier, 1891

Henricia diffidens (Koehler, 1923) *

ORDEN VALVATIDA Perrier, 1884

FAMILIA ASTERINIDAE Gray, 1840

Asterina fimbriata Perrier, 1875

Asterina stellifera (Möbius, 1859)

FAMILIA GANERIIDAE Sladen, 1889

Cycethra verrucosa (Philippi, 1857

Cycethra verrucosa verrucosa (Philippi, 1857)

Ganeria falklandica Gray, 1847

Ganeria hahni Perrier, 1891 
FAMILIA GONIASTERIDAE Forbes, 1841 Ceramaster patagonicus (Sladen, 1889) Ceramaster grenadensis patagonicus (Sladen, 1889)* Cladaster analogus Fisher, 1940 Hippasteria falklandica Fisher, 1940 Hippasteria phrygiana argentinensis Bernasconi, 1961

FAMILIA ODONTASTERIDAE Verrill, 1899 Acodontaster e. granuliferus (Koehler, 1912) Diplodontias singularis granulosus Perrier, 1891 Odontaster penicillatus (Philippi, 1870)

FAMILIA PORANIIDAE Perrier, 1875

Porania (Porania) antarctica magellanica Studer, 1876 Porianiopsis mira de Loriol, 1904)

ORDEN VELATIDA Perrier, 1884

FAMILIA PTERASTERIDAE Perrier, 1875

Diplopteraster clarki Bernasconi, 1937

Diplopteraster verrucosus (Sladen, 1882)

Pteraster affinis lebruni Perrier, 1891

Pteraster gibber (Sladen, 1882) *

Pteraster stellifer Sladen, 1882

FAMILIA SOLASTERIDAE Viguier, 1878

Lophaster stellans Sladen, 1889

Solaster regularis Sladen, 1889

FAMILIA MYXASTERIDAE

Pythonaster murrayi Sladen, 1889 *

CLASE OPHIUROIDEA Gray, 1840

ORDEN OPHIURIDA Müller \& Troschel, 1840

FAMILIA AMPHIURIDAE Ljungman, 1867

Amphiodia planispina (v. Martens, 1867)

Amphioplus albidus (Ljungman, 1867)

Amphiura crassipes Ljungman, 1867

Amphiura eugeniae Ljungman, 1867

Amphiura joubini Koehler, 1912

Amphiura magellanica Ljungman, 1867

Amphiura princeps Koehler, 1907

Amphiura lymani Studer, 1885 *

Amphipholis squamata (Delle Chiaje, 1828) *

FAMILIA OPHIACANTHIDAE Ljungman, 1867 Ophiacantha vivipara Ljungman, 1870 Ophiacantha densispina Mortensen, 1836 * Ophiochondrus stelliger Lyman, 1879

FAMILIA OPHIACTIDAE Matsumoto, 1915 Ophiactis asperula (Philippi, 1858)

FAMILIA OPHIOLEPIDIDAE Ljungman, 1867 Ophiomusium archaster Lyman, 1878 * Ophioplocus januarii (Lütken, 1856)

Ophiozonella falklandica Mortensen, 1936 *

FAMILIA OPHIOMYXIDAE Ljungman, 1867 Ophiolycus nutrix (Mortensen, 1936) * Ophiomyxa vivipara Studer, 1876

FAMILIA OPHIURIDAE Müller \& Troschel, 1840 Ophioplinthus inornata (Lyman, 1878) Ophiocten amitinum Lyman, 1878

Ophiolebella biscutifera (G. A. Smith, 1923) Ophiura (Ophiuroglypha) carinifera (Koehler, 1901) Ophiura (Ophiuroglypha) lymani (Ljungman, 1871)

ORDEN EURYALIDA Lamarck, 1816

FAMILIA GORGONOCEPHALIDAE Ljungman, 1867 Astrotoma agassizii Lyman, 1875
Gorgonocephalus chilensis (Philippi, 1858)

CLASE ECHINOIDEA Leske, 1778

ORDEN ARBACIOIDA Gregory, 1900

FAMILIA ARBACIIDAE Gray, 1855

Arbacia dufresnii (Blainville, 1825)

ORDEN CIDAROIDA Claus, 1880

FAMILIA CIDARIDAE Gray, 1825

Austrocidaris canaliculata (A. Agassiz, 1863)

Austrocidaris spinulosa Mortensen, 1910

ORDEN CAMARODONTA Jackson, 1912

FAMILIA ECHINIDAE Gray, 1825

Sterechinus agassizii Mortensen, 1910

FAMILIA TEMNOPLEURIDAE A. Agassiz, 1872

Pseudechinus magellanicus (Philippi, 1857)

ORDEN CLYPEASTEROIDA L. Agassiz 1835

FAMILIA MELLITIDAE Stefanini, 1912

Encope emarginata (Leske, 1778)

Leodia sexiesperforata (Leske, 1778) *

ORDEN SPATANGOIDA L. Agassiz, 1840a

FAMILIA PRENASTERIDAE Lambert, 1905

Parapneustes reductus Koehler, 1912 *

Tripylus excavatus Philippi, 1845

FAMILIA SCHIZASTERIDAE Lambert, 1905

Abatus agassizii (Pfeffer, 1889)

Abatus cavernosus (Philippi, 1845)

Abatus philippii Lovén, 1871

Aceste bellidifera Thomson, 1877 *

Tripylaster philippii (Gray, 1851)

CLASE HOLOTUROIDEA

ORDEN APODIDA Brandt, 1835

FAMILIA CHIRIDOTIDAE Østergren, 1898

Chiridota marenzelleri Perrier R, 1904

Chiridota pisanii Ludwig, 1887

Taeniogyrus contortus (Ludwig, 1875)

Trochodota purpurea Pawson, $1969 *$

ORDEN DENDROCHIROTIDA

FAMILIA CUCUMARIIDAE Ludwig, 1894

Cladodactyla crocea (Lesson, 1830) Panning, 1949

Hemioedema spectabilis (Ludwig, 1883)

Pseudocnus cornutus (Cherbonnier, 1941)

Pseudocnus dubiosus leoninus (Semper, 1867)

Pseudocnus perrieri (Ekman, 1927) Panning, 1963

Trachythyone parva (Ludwig, 1875)

Trachythyone peruana (Semper, 1868)

FAMILIA PARACUCUMIDAE Pawson \& Fell, 1965

Ekmocucumis steineri (Ludwig, 1886)

FAMILIA PHYLLOPHORIDAE Oestergren, 1907

Pentamera chiloensis (Ludwig, 1887)

FAMILIA PSOLIDAE Perrier, 1902

Psolidium dorsipes Ludwig, 1887

Psolus antarcticus Philippi, 1857 *

Psolus murrayi Théel, 1886 *

Psolus patagonicus Ekman, 1925

CLASE CRINOIDEA Miller, 1821

ORDEN COMATULIDA

FAMILIA ANTEDONIDAE Norman, 1865

Phrixometra nutrix (Mortensen, 1918)

Isometra vivipara (Mortensen, 1917) 
Appendix 2.- List of publications used in the preparation of the historical database.

\begin{tabular}{|c|c|c|}
\hline 1 & Agassizi A. 1881 & $\begin{array}{l}\text { Report on the Echinoidea. Zoology } 9 \text { IX } 321 \text { pages with } 66 \text { plates. In Report of the } \\
\text { Challenger expedition Volumen } 3 \text {. London. }\end{array}$ \\
\hline 2 & Bastida R., Roux A., Martinez D. 1992 & Benthic communities of the Argentine continental shelf. Oceanol. Acta 15. \\
\hline 3 & Bernasconi I. 1937 & $\begin{array}{l}\text { Asteroideos argentinos I: Familia Pterasteridae. Anales del Museo Argentino de Cien- } \\
\text { cias Naturales "Bernardino Rivadavia" 39: 167-187. }\end{array}$ \\
\hline 4 & Bernasconi I. 1941 & $\begin{array}{l}\text { Los equinodermos de la expedición del Buque Oceanográfico "Comodoro Rivadavia" } \\
\text { ARA. Physis 19: } 37-49 \text {, lams 1-8, } 30 \text { figs. }\end{array}$ \\
\hline 5 & Bernasconi I. 1943 & $\begin{array}{l}\text { Los asteroideos sudamericanos de la familia Luidiidae. Anal. Mus. Argentino Cien. } \\
\text { Nat. "Bernardino Rivadavia" 61: 1-20. }\end{array}$ \\
\hline 6 & Bernasconi I. 1953 & $\begin{array}{l}\text { Monografía de los equinoideos argentinos. Anal. Mus. Hist. Nat. Montevideo. Seg- } \\
\text { unda ser. } 6(2): 1-58 \text {. }\end{array}$ \\
\hline 7 & Bernasconi I. 1962 & $\begin{array}{l}\text { Asteroideos argentinos III: Familia Odontasteridae. Rev. Museo Argentino Cienc. Nat. } \\
\text { "Bernardino Rivadavia" Cienc. Zool. 8(3): 27-51. }\end{array}$ \\
\hline 8 & Bernasconi I. 1963 & $\begin{array}{l}\text { Asteroideos argentinos IV: Familia Goniasteridae. Rev. Museo Argentino Cienc. Nat. } \\
\text { "Bernardino Rivadavia" Cienc. Zool. 9: 1-26. }\end{array}$ \\
\hline 9 & Bernasconi I. 1964 & $\begin{array}{l}\text { Asteroideos argentinos V: Familia Ganeriidae. Rev. Museo Argentino Cienc. Nat. } \\
\text { "Bernardino Rivadavia" Cienc. Zool. 9(4): 59-89. }\end{array}$ \\
\hline 10 & Bernasconi I. 1966 & $\begin{array}{l}\text { Los equinoideos y asteroideos colectados por el buque oceanográfico R/V "Vema", } \\
\text { frente a las costas argentinas, uruguayas y sur de Chile. Rev. Museo Argentino Cienc. } \\
\text { Nat. "Bernardino Rivadavia" Cienc. Zool. 9(7): 147-175, 2pls. }\end{array}$ \\
\hline 11 & Bernasconi I. 1973 & $\begin{array}{l}\text { Los equinodermos colectados por el "Walter Herwing" en el Atlántico Sudoeste. Rev. } \\
\text { Museo Argentino Cienc. Nat. "Bernardino Rivadavia" Hidrobiol. 3(3): 287-334. }\end{array}$ \\
\hline 12 & Bernasconi I., D’Agostino, 1977 & $\begin{array}{l}\text { Ofiuroideos del mar epicontinental argentino. Rev. Museo Argentino Cienc. Nat. } \\
\text { "Bernardino Rivadavia" 5(5): 65-114. }\end{array}$ \\
\hline 13 & Bernasconi I. 1979 & $\begin{array}{l}\text { Asteriidae, Cosconasteriinae de la Argentina y Antártida. Rev. Museo Argentino } \\
\text { Cienc. Nat. "Bernardino Rivadavia" Hidrobiol. 5(11): } 241-249 \text {. }\end{array}$ \\
\hline 14 & Bernasconi I. 1980 & $\begin{array}{l}\text { Asteroideos argentinos VII. Familia Echinasteridae } \\
\text { Revista del Museo Argentino de Ciencias Naturales "Bernardino Rivadavia" Hidrobi- } \\
\text { ología, } 4 \text { (12), 247-258. }\end{array}$ \\
\hline 15 & Bremec C., Roux A. 1997 & $\begin{array}{l}\text { Resultados del análisis de una campaña de investigación pesquera, sobre comunidades } \\
\text { bentónicas asociadas a bancos de mejillón (Mytilus edulis platensis D’Orb.) en costas } \\
\text { de Buenos Aires, Argentina. Rev. Invest. Desarr. Pesq. 11: 153-166. }\end{array}$ \\
\hline 16 & Callebaut J., Borzone C. 1979 & $\begin{array}{l}\text { Observaciones ecológicas del infralitoral de Puerto Deseado (Provincia de Santa Cruz, } \\
\text { Argentina) I. Península Foca Ecosur, 6(11): 45-54. }\end{array}$ \\
\hline 17 & $\begin{array}{l}\text { Carriquiriborde L., Borzone C., Lizarralde Z., } \\
\text { Pombo A., Manriquez R., Ichazo, M. } 1982\end{array}$ & $\begin{array}{l}\text { Aspectos Biocenológicos del Golfo Nuevo (Chubut-Argentina). VIII Simposio sobre } \\
\text { Oceanografía Biológica. Montevideo Uruguay. }\end{array}$ \\
\hline 18 & Fisher, W.K., 1940 & Asteroidea. Discovery Reports 20: 69-306. pls. 1-23. \\
\hline 19 & Giberto D., Bremec C. 2005 & $\begin{array}{l}\text { Benthic diversity of the Río de la Plata Estuary and adjacent Marine Waters. Freplata, } \\
\text { Montevideo Uruguay }\end{array}$ \\
\hline 20 & Hernandez D., Tablado A. 1985 & $\begin{array}{l}\text { Asteroidea de Puerto Deseado (Santa Cruz, Argentina). Contribución Científica N No } 193 \\
\text { del Centro de Investigación de Biología Marina (CIBIMA), } 16 \text { pp. }\end{array}$ \\
\hline 21 & Hernandez D. 1981 & $\begin{array}{l}\text { Holothuroidea de Puerto Deseado (Santa Cruz, Argentina). Rev. Museo Argentino } \\
\text { Cienc. Nat. "Bernardino Rivadavia" 4: 151-168. }\end{array}$ \\
\hline 22 & Lyman T. 1882 & $\begin{array}{l}\text { Report on the Ophiuroidea. Zoology } 14 \text { XIV, } 387 \text { pages with } 48 \text { plates. In Report of } \\
\text { the Challenger Expedition Volumen 5. London. }\end{array}$ \\
\hline 23 & Milstein A., Juanico M., Olazarri J. 1976 & $\begin{array}{l}\text { Algunas asociaciones bentónicas frente a las costas de Rocha, Uruguay. Resultados } \\
\text { de la campaña del R/V "Hero", viaje 72-3A. Com. Soc. Malac. Urug. Vol IV, 30, } \\
\text { 143-164 }\end{array}$ \\
\hline 24 & Mortensen, T. 1936 & Echinoidea and Ophiuroidea. Discovery Reports 12: 199-348, Plates I-IX. \\
\hline 25 & Olivier S., Bastida R., Torti M. 1968 & $\begin{array}{l}\text { Resultados de las Campañas Oceanográfica I-V. Contribución al trazado de una carta } \\
\text { bionómica del área de Mar del Plata. Bol. Inst. Biol. Mar. 16: 1-85. }\end{array}$ \\
\hline 26 & Roux A., Bremec C. 1996 & $\begin{array}{l}\text { Comunidades bentónicas relevadas en las transacciones realizadas frente al Río de La } \\
\text { Plata }\left(35^{\circ} 15^{\prime} \mathrm{S}\right) \text {, Mar del Plata }\left(38^{\circ} 10^{\prime} \mathrm{S}\right) \text { y Península de Valdes }\left(42^{\circ} 35^{\prime} \mathrm{S}\right) \text {, Argentina. } \\
\text { Contribución INIDEP N } \mathrm{N}^{\circ} 938,13 \mathrm{pp} \text {. }\end{array}$ \\
\hline 27 & Roux A., Fernandez M. 1997 & $\begin{array}{l}\text { Caracterización de los fondos de pesca de langostino patagónico Pleoticus muelleri en } \\
\text { el golfo San Jorge y litoral de la provincia de Chubut-Argentina. INIDEP Inf. Técnico } \\
13\end{array}$ \\
\hline 28 & Roux A., Fernández M., Bremec C. 1995 & $\begin{array}{l}\text { Estudio preliminar de las comunidades bentónicas de los fondos de pesca de langos- } \\
\text { tino patagónico del golfo San Jorge (Argentina). Cienc. Mar. 21(3), 295-310. }\end{array}$ \\
\hline 29 & Roux A., Bastida R., Bremec C. 1993 & $\begin{array}{l}\text { Comunidades bentónicas de la plataforma continental argentina. Campañas transec- } \\
\text { ción BIP “Oca Balda” 1987/88/89. Boletin del Instituto Oceanográfico, San Pablo, } \\
\text { 41(1/2), 81-94. }\end{array}$ \\
\hline 30 & $\begin{array}{l}\text { Roux A., Bastida R., Lichtschein V., } \\
\text { Barreto A. } 1988\end{array}$ & $\begin{array}{l}\text { Investigaciones sobre las comunidades bentónicas de plataforma a través de una tran- } \\
\text { secta frente a Mar del Plata. Spheniscus, } 6,19-52 \text {. }\end{array}$ \\
\hline 31 & Sladen W.P. 1889 & $\begin{array}{l}\text { Report on the Asteroidea. Zoology } 51 \text { LI, } 893 \text { pages with } 117 \text { plates. In Report of the } \\
\text { Challenger expedition Volumen } 30 \text {. London. }\end{array}$ \\
\hline 32 & Tablado A. 1982 & $\begin{array}{l}\text { Asteroideos argentinos. Familia Poraniidae. Com. Mus. Arg. Cs. Nat., Hidrob., Argen- } \\
\text { tina, 2(2), 87-106. }\end{array}$ \\
\hline 33 & Tablado A., Maytia S. 1988 & $\begin{array}{l}\text { Presencia de Perissasterias polyacantha H.L. Clark } 1923 \text { (Echinodermata, Asteroidea) } \\
\text { en el Atlántico sudoccidental. Com. Zool. Mus. Hist. Nat. Montivideo, Uruguay, } 12 \\
\text { (169), 1-11. }\end{array}$ \\
\hline 34 & Tommasi 1., Cernea M. Condeixa M. 1988 & $\begin{array}{l}\text { Equinodermos colectados pelo N/Oc. “Almirante Saldanha”, entre } 26^{\circ} 59^{\prime} \mathrm{S} \text { e } 38^{\circ} 39^{\prime} \mathrm{S} \text {. } \\
\text { Relat. Int. Inst. Oceanogr. Univ. S. Paulo, 22, } 11 \text { pp. }\end{array}$ \\
\hline 35 & Theel, H. 1882 & Report on the Holothuroidea 1. Challenger Scientific Results. Zoology, 4: 1-136. \\
\hline 36 & Theel, H. 1886 & Report on the Holothurioidea 2. Challenger Scientific Results. Zoology, 14: 1-290. \\
\hline
\end{tabular}

